tions and the higher education sector for an uncertain future. Questions such as how does one balance the pursuit of public purposes with the demands of a competitive marketplace? or how can higher education's key values be articulated and reaffirmed as steadfast priorities given the new environment and the constantly changing nature of public policy? will need to be addressed if American higher education is to preserve the best of its traditions and capitalize on the opportunities that lie before it.

Author's note. This article is based on a paper, the fourth in series of essays, capturing three roundtable conversations among 40 leaders of American universities and colleges and other higher education leaders. The essays can be found on the website of the American Council on Education (http://www.acenet.edu/bookstore) under Leadership and Institutional Effectiveness. The project was supported by Fidelity Investments.

\title{
China's Private Higher Education: The Impact of Public-Sector Privatization
}

\begin{abstract}
Yingxia Cao and Daniel C. LeVy
Daniel C. Levy is a Distinguished Professor at the State University of New York and director of PROPHE. E-mail: dlevy@albany.edu. Yingxia Cao is a PROPHE doctoral research associate.E-mail: yisacao@hotmail.com. Both authors are in the Department of Educational Administration Q Policy Studies, SUNY-Albany. Address: Education Building, SUNY at Albany, Albany, NY 12222, USA.

IHE devotes space each issue to contributions from PROPHE, the Program for Research on Private Higher Education, headquartered at the University of Albany. See http://www.albany.edu/.
\end{abstract}

A $\mathrm{s}$ in many countries, the emergence of private higher education initially seemed rather apart from the development of public higher education in China. The public sector could not meet the increasing demand for higher education, and the private sector thus helped fill the gap. However, as private higher education has grown more robust-and as public higher education has partly privatized-competitive intersectoral competition has become more dynamic.

\section{The Growth of Private Higher Education}

Chinese private higher education reemerged in the late I970s, after having been abolished in an earlier period, and has now expanded enormously. Whereas only a handful of private institutions, with limited enrollments, existed in I980, by I999 the number of private institutions had reached I,270-outnum- bering public institutions by three to four hundred. Private enrollments grew to over one million, giving China one of the largest private higher education sectors in the world. Estimates on the private sector's share of total enrollments have ranged from a fourth to even a third, although only about 40,000 of these students were in programs recognized by the Ministry of Education and thus permitted to grant bachelor's or associate degrees.

The dawn of the new century is witnessing an important change in the development of China's private higher education. Although the number of private institutions and their enrollments decreased for the first time in 2000 , the decline lasted just a year. At the same time, the number of private institutions with the standing to offer degrees has more than doubled, from 89 to over 200 , and overall private enrollments are resuming their substantial growth. These characteristics suggest an upward trend in many private institutions' quality and capacity.

Scholars and practitioners generally agree that the resurgence as well as initial development of private higher education took advantage of the public sector's failure to meet the rapidly growing demand (of students and employers alike), because of institutional inertia, financial shortfalls, and policy restrictions. In contrast, the private sector proved eager and flexible enough to absorb some of the new demand. While these dynamics have been common in many countries, they do not fully explain the more recent shifts in Chinese private higher education development (which have parallels in other countries).

These colleges are owned (at least partially) or managed by private parties, classified by government as part of the private sector, but affiliated to public universities.

\section{The Privatization of Public Higher Education}

The striking public-sector privatization presents at least three challenges to private higher education development in China. One challenge involves the introduction of affiliated colleges since i999. These colleges are owned (at least partially) or managed by private parties, classified by government as part of the private sector, but affiliated to public universities. They become a new type of provider, often with competitive advantages (conferred through their public university) over the existing independent private institutions in prestige, size, financing, and level of education provision. Although established with private financing and under independent management, affiliated private institutions usually receive important academic resources and gain enhanced reputations from the prestigious universities to which they may be linked. They are allowed to grant baccalaureate degrees, without having to go 
through the usual accreditation procedure. In comparison to the public universities to which they are affiliated, these institutions are permitted to enroll a considerable number of students with lower entrance examination scores but at much higher tuition rates. Consequently, many independent private institutions are left with a greatly diminished ability to attract students and investments.

A second critical challenge is the privatization of public-sector financing, which allows public institutions to expand enrollment capacity quickly. This obviously undercuts private higher education expansion. The two major privatized financing sources for public higher education consist of tuition and bank loans. While tuition compensates for the state's decreasing allocation, bank loans allow public institutions to garner as much as hundreds of millions of dollars. Such funds pose extraordinary enrollment challenges to private higher education because public institutions enhance their existing programs and add new programs and campuses.

A third challenge to China's private higher education involves public institutions' privatized management style, which imitates private business as well as the private higher education sector by adopting a market orientation. Public institutions not only improve their efficiency in management but also update their curriculum and programs, based on market demands. Private institutions thus have to reexamine their management efficiency and compete with public institutions in certain marketable fields that used to be the private sector's exclusive profitable domain.

\section{The Modification of Private Higher Education}

As the challenges from public-sector privatization modify China's private higher education development, two key trends emerge. One trend is the bifurcation of private institutions. Some institutions accumulate enormous resources, upgrade their educational quality, update program provision, enroll thousands of students, and thus gain considerable prestige and recognition while competing with public, affiliated, and other independent private institutions. But more and more independent private institutions experience hardship from the fierce new competition. Closings and mergers (from positions of weakness) are increasing.

The second trend is that the future of independent private institutions is increasingly obscure because of the rapid spread of degree-granting affiliated colleges. As the latter enjoy certain inherent advantages, numerous nonprestigious independent private colleges thus often need to accept the weakest applicants, in nondegree programs. The competition is especially difficult because China is experiencing a gradually shrinking pool of high school graduates who fail to gain admission to public universities.

While China's private higher education used to take advantage of the limited public provision, the new intersectoral competitive dynamics now present a challenge to private higher education's growth. This trend is also significantly modifying the development pattern and shape of the country's private higher education sector.

\section{New Private-Public Dynamics: Graduate Education in Uruguay}

\section{Pablo Landon I Couture}

Pablo Landoni Couture is a professor at the Catholic University of Uruguay and a PROPHE affiliate: Address: Av. 8 de Octubre 2738 Montevideo, URUGUAY CP 11600. E-mail: plandoni@ucu.edu.uy.

$\mathrm{U}$ ruguay was the last country in Latin America to authorize private higher education institutions. Current regulatory and financing arrangements contribute to a still rather limited private-public competition but that may be changing, and the graduate level is a key locus of such new competition.

\section{A New Private Sector}

Private higher education was not allowed in Uruguay until I985, when the government authorized the founding of the Catholic University. Ten years later, a new regulation was passed, opening the way for ample private growth.

Since 1995, I7 private higher education institutions have been recognized by the state. In the past Io years, the sector has expanded and now offers 98 academic programs at the undergraduate and graduate levels. Uruguay's private sector now holds I2 percent of total national enrollments, although this percentage remains far below the private sector's share in Chile, Brazil, and other countries in the region, some of which have more than half the enrollments in the private sector.

The venerable University of the Republic (Universidad de la República) is the country's only public university. It has a rather open admissions policy, and it does not charge tuition. As a consequence, the private sector is constrained in its ability to attract students, especially from low- and middle-income families. This dual nature of the system, in terms of finance, is the main reason why private-public competition at the undergraduate level remains limited.

\section{Graduate Education}

From the beginning, Uruguay's private higher education institutions developed programs at the graduate level. This focus contrasts with the almost exclusive undergraduate emphasis of early decades in the private sector in most Latin American countries. Uruguay's private higher education leaders saw graduate education as an area in which they could successfully compete with the public university.

The University of the Republic has mostly followed the traditional Napoleonic model inherited by a good number of pub- 